\title{
Diversity in Shade and Light Leaf Morphology in Beech Populations of South Rodopi Mountains
}

\author{
Stefanos Boutsios $^{1} \cdot$ Amaryllis Vidalis $^{1,2}$ (D) - George C. Adamidis ${ }^{3}$ (D) \\ Seraphim Hatziskakis ${ }^{1}$. Georgios Varsamis $^{1}$ - Ioannis Tsiripidis ${ }^{4}$ (D) \\ Paraskevi Karanikola ${ }^{1}$ (D) - Aristotelis C. Papageorgiou ${ }^{5}$ (D)
}

Received: 27 March 2020/Revised: 21 September 2020/Accepted: 22 October 2020/Published online: 9 November 2020

(C) The Author(s) 2020

\begin{abstract}
The size and shape of tree leaves and their variation within the canopy are the result of both physiological plasticity and an overall adaptive strategy against unfavourable environmental conditions. In this study, diversity patterns at leaf morphological traits will be described within and among populations of trees with different phylogenetic background. Beech (Fagus sp.) is a widespread tree in Eurasia, represented by two species; $F$. sylvatica in Europe and F. orientalis in eastern Europe and Asia. Both species appear in the Rodopi mountains, in southeast Balkans. Five beech populations were sampled in the southern slopes of Rodopi along a west-east gradient representing an established transitional zone between the two beech species. The diversity of six leaf traits was examined in shade leaves and leaves exposed to direct
\end{abstract}

Significance Statement This work helps understand the adaptation strategies plants use to cope with adverse environmental conditions and the potential of different species and populations to adapt towards climate change. This will contribute to the design of management and conservation measures for commercially important tree species such as beech.

George C. Adamidis

gcadamidis@gmail.com

1 Faculty of Forestry, Environmental Management and Natural Resources, Democritus University of Thrace, Orestiada, Greece

2 Institute for Forest Genetics and Forest Tree Breeding, University of Göttingen, Göttingen, Germany

3 Institute of Ecology and Evolution, University of Bern, Bern, Switzerland

4 Department of Botany, School of Biology, Aristotle University of Thessaloniki, Thessaloniki, Greece

5 Faculty of Molecular Biology and Genetics, Democritus University of Thrace, Alexandroupolis, Greece irradiation. Significant differences appeared among populations and among the two shading classes. Western beech populations consisted of trees with smaller leaves and fewer veins and were morphologically closer to $F$. sylvat$i c a$, while eastern populations seemed to be closer to $F$. orientalis. Shade leaves were constantly larger and less round than light leaves, probably due to different light harvesting strategies. The differences between populations were larger for shade leaves than for light leaves and presented a clear east-west trend, consistent to the differentiation pattern provided by previous genetic studies in the same region. Our results indicate that shade leaves probably maintain their size and shape independent from light irradiation and therefore may better express genetic differences among populations.

Keywords Fagus sylvatica - Fagus orientalis . Leaf morphometrics - Leaf traits - Adaptation

\section{Introduction}

Plant leaves are optimized organs for light capture, and their morphological attributes define their functionality. They show morphological differences among taxa and for this reason they have been used for classification in plant systematics [1]. However, leaf morphotypes are not uniform within individual plants, especially large trees. Leaves often demonstrate differences in their shape and size, according to their position within the canopy $[2,3]$. In broadleaved trees, leaves that are exposed to direct sunlight (hereafter light leaves) tend to become smaller in size and thicker than leaves located in the inner part of the canopy (hereafter shade leaves). This morphological variation is considered to occur as a plastic response of leaves to 
different environmental conditions that exist within the canopy, but also to be an outcome of an overall plant adaptive strategy to best balance between different resource limitations and ontogenetic restrictions [1]. This adaptive strategy is believed to be in a large proportion of genetic nature [2] and to play an important role in the response of tree species towards climate change.

Beech (Fagus sp.) is an important widespread forest tree in Eurasia, characterized by large morphological diversity. The latest classification suggests two beech species, Fagus sylvatica $\mathrm{L}$. in Europe and Fagus orientalis Lipsky in N. Iran, N. Turkey, Caucasus, Crimea, Transcaucasia and SW Balkans [4]. The morphological distinction of these species is difficult, since they exhibit richness in overlapping morphotypes, but also due to a possible introgressive hybridization between them, that may have occurred in the south-eastern part of the Balkan peninsula, where the two species have probably come in contact in the past [5-8]. Leaves of $F$. sylvatica and $F$. orientalis have been described in several studies [9, 10], with the latter having on average larger laminas with more secondary nerve pairs, an elongated and reverse ovate shape and usually shorter petioles. In contrast, $F$. sylvatica is reported to have shorter laminas with fewer nerve pairs, a rounder lamina shape and longer petioles [11]. Beech forests cover a large part of the mountainous zone in central and northern Greece, with both beech species present. Tree morphotypes close to $F$. orientalis are mainly found in the north-eastern part of the country, especially in the Rodopi mountains, where the diversity of morphological characters is very high [9]. In western Rodopi beech resembles $F$. sylvatica in its morphological characteristics, while forms resembling $F$. orientalis are rare and restricted to low altitudes. On the other hand, in the eastern part of the mountain, the frequency of beech trees having $F$. orientalis morphological characteristics increases, while forms resembling $F$. sylvatica seem to be rare. Previous genetic studies using chloroplast DNA (cpDNA) haplotypes and random genomic markers have confirmed an east-west diversity cline of beech in the mountains and suggested that the southern Rodopi mountains constitute a transitional zone between the two beech species [7].

Since light leaves are exposed more directly to environmental conditions, therefore, they are expected to demonstrate a more restricted range of morphotypes that is less related to genetic differences between populations and taxa, than shade leaves. We can therefore hypothesize that, when considering tree populations with known phylogenetic differences, the diversity patterns of morphological traits in shade leaves will reflect phylogenetic differences in a more profound way than in light leaves. In order to test this hypothesis, we studied leaf morphology in beech populations having a different biogeographical background, along an east-west gradient in the Rodopi mountains. The aim of this study is to describe variation patterns in leaf morphological traits, both in light and shade leaves, in five beech populations in Rodopi with different biogeographical background, testing the hypothesis that morphological differences among populations may differ between shade and light leaves, expressing different levels of influence from environmental heterogeneity and different adaptation strategies.

\section{Material and Methods}

Leaf samples were collected from five beech populations in Rodopi, NE Greece, providing a geographical gradient from West to East (Table 1, Fig. 1), possibly representing populations with different beech species composition (see above). A total of 25 adult trees with a symmetrical, fully grown canopy, were randomly selected in each population, and 20 healthy and fully expanded leaves were randomly collected from each tree. Ten leaves were collected from the outer part of the canopy (light leaves) and ten from the inner part of the canopy (shade leaves). In each sampled leaf, we measured six morphological traits: Lamina length (Length), lamina width (Width), number of secondary vein pairs (Veins), petiole length (Petiole), leaf index (LI = Leaf length/Leaf width $\times 100$ ), maximum width index (MWI $=$ distance between the lower point of the lamina and the maximum width point on the axis/Leaf length $x$ 100). All measurements were carried out on scanned digital images of the leaves, using Image-Pro Plus (MediaCybernetics $\left.{ }^{\circledR}\right)$. The traits used in this study were selected due to their importance in the characterization of beech taxa and their ability to capture the increased morphological variation in beech populations in Eurasia $[9,12]$. Average values were estimated for each tree for all traits, for each population and shading level. Means were compared using one- and two-way ANOVA with R package Rcmdr [13]. A principal component analysis (PCA) was used to describe relationships among variables, groups of variables and populations for light and shade leaves using FactoMineR [14].

\section{Results and Discussion}

Mean values of length and width, veins and MWI were highly significantly different among populations both for light and shade leaves (Table 2). These four traits had significantly different values between light and shade leaves. No significant interaction between subpopulations and shading class was found (Table 2). Western beech populations (Elatia, Haidu) had trees with smaller leaves 
Table 1 Geographic position and altitude of populations

\begin{tabular}{llll}
\hline Population & Latitude & Longitude & Altitude $(\mathrm{m})$ \\
\hline Elatia & $41^{\circ} 28^{\prime}$ & $24^{\circ} 18^{\prime}$ & 1500 \\
Haidu & $41^{\circ} 19^{\prime}$ & $24^{\circ} 41^{\prime}$ & 1300 \\
Echinos & $41^{\circ} 17^{\prime}$ & $24^{\circ} 58^{\prime}$ & 800 \\
Papikio & $41^{\circ} 14^{\prime}$ & $25^{\circ} 25^{\prime}$ & 900 \\
Dadia & $41^{\circ} 17^{\prime}$ & $26^{\circ} 01^{\prime}$ & 700 \\
\hline
\end{tabular}

and fewer veins. This pattern was less evident in light leaves, but appeared clearly in shade leaves (Table 2, Fig. 2a). Petiole length was not significantly different between populations. Leaf shape (LI and MWI) showed an east-west pattern as well, although this pattern was not as strong as for leaf size and was only observed in shade leaves (Fig. 2b). Eastern beech populations (Ehinos, Papikio, Dadia) appeared to have trees with more elongated and reverse ovate shade leaves compared to the western populations.

Considering the botanical description of both beech species occurring in the region, our results indicate that beech populations on the western side of the Rodopi mountains were morphologically closer to $F$. sylvatica, while populations on the eastern side of Rodopi seemed to be closer to $F$. orientalis. An introgression zone in NE Greece, where the two beech species presumably meet, has been suggested by several authors, based on morphological traits, vegetation zones and genetic markers $[8,9,15,16]$. Our results support this scenario and confirm the observations of previous studies that report of possible species-related morphological differences in beech leaves on an east-west gradient in Rodopi [17]. However, such morphological differences in lamina size and shape can also occur between beech populations growing on different altitudes, as is the case with the populations studied here (Table 1). Since altitude is correlated with temperature and water availability, the variability of leaf size and shape may express ecological adaption [18, 19]. Furthermore, differences between shade and light leaves show that exposure to light can influence their size, as reported for beech [20-22] and other broadleaved tree species [2, 23, 24]. Shade leaves express a different light harvesting strategy than light leaves and their size and shape seem to aim the maximum extension of the leaf area in order to absorb more light in the lower part of the dense beech canopy $[1,25]$. Typically, shade tolerant trees such as beech, have the trend to form a closed canopy and keep the interior canopy part under low irradiation, where a relatively high photosynthetic activity is maintained [20]. This is usually achieved by developing larger but thinner leaves under low light irradiation, as was confirmed in our study regarding the size of shade leaves.

In our study, the differences in leaf size and shape between eastern and western beech populations were observed mainly at shade leaves, which had a similarly low exposure to irradiation. We assume that genetic differences among the studied populations were better reflected in shade leaves, since light leaves are influenced by direct irradiation, probably more than by the genetic background of each tree. It is thus possible to have a more direct
Fig. 1 Location of populations in north-eastern Greece. Grey coloured areas represent elevations of 500-1000 $\mathrm{m}$ and black coloured areas elevations above $1000 \mathrm{~m}$

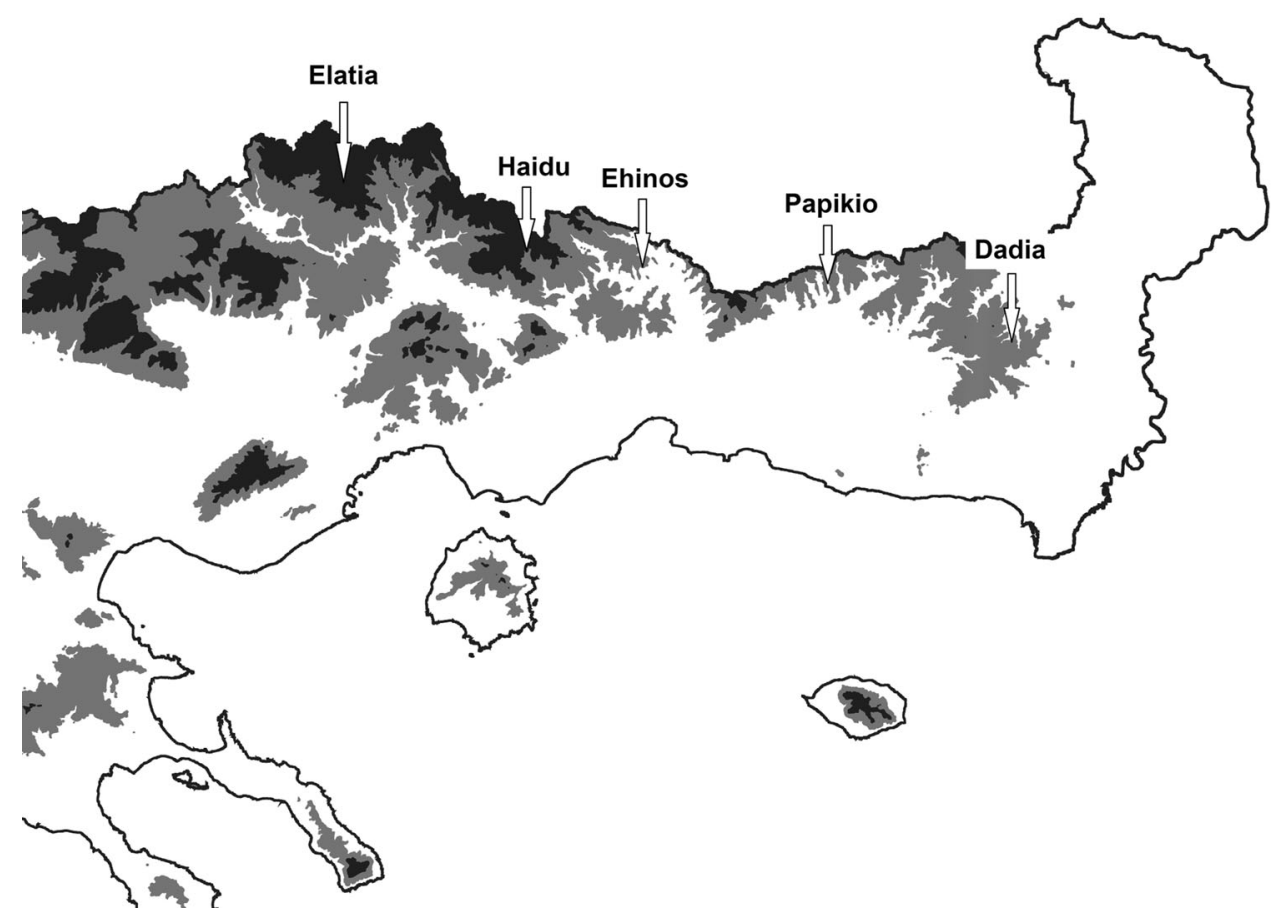


Table 2 Means and Analysis of Variance (ANOVA) of leaf traits for five populations, two levels of shading and the population $\mathrm{x}$ shading interaction $(\mathrm{SD}=$ standard deviation, $\mathrm{ns}=$ non significant,
$*=$ significant at $5 \%, * *=$ significant at $1 \%$ and $* * *=$ significant at $1 \%)$. Letters in bold denote the significance groups according to the Tukey contrasts (at $P<0.05$ )

\begin{tabular}{|c|c|c|c|c|c|c|c|}
\hline \multicolumn{2}{|c|}{ Light leaves } & \multirow{2}{*}{$\begin{array}{l}\text { Length } \\
7.40 \mathbf{a b} \\
(0.65)\end{array}$} & \multirow{2}{*}{$\begin{array}{l}\text { Width } \\
4.56 \mathbf{a b} \\
(0.41)\end{array}$} & \multirow{2}{*}{$\begin{array}{l}\text { LI } \\
163.2 \\
(11.97)\end{array}$} & \multirow{2}{*}{$\begin{array}{l}\text { MWI } \\
51.6 \mathbf{a b} \\
(2.45)\end{array}$} & \multirow{2}{*}{$\begin{array}{c}\text { Petiole } \\
0.92 \\
(0.16)\end{array}$} & \multirow{2}{*}{$\begin{array}{l}\text { Veins } \\
16.3 \mathbf{a} \\
(1.38)\end{array}$} \\
\hline Elatia & $\begin{array}{l}\text { Mean } \\
(\mathrm{SD})\end{array}$ & & & & & & \\
\hline Haidu & $\begin{array}{l}\text { Mean } \\
(\mathrm{SD})\end{array}$ & $\begin{array}{l}6.90 \mathbf{a} \\
(0.70)\end{array}$ & $\begin{array}{l}4.35 \mathbf{a} \\
(0.38)\end{array}$ & $\begin{array}{l}159.1 \\
(12.06)\end{array}$ & $\begin{array}{c}53.0 \text { b } \\
(2.46)\end{array}$ & $\begin{array}{c}0.85 \\
(0.11)\end{array}$ & $\begin{array}{r}16.6 \mathbf{a} \\
(1.30)\end{array}$ \\
\hline Ehinos & $\begin{array}{l}\text { Mean } \\
(\mathrm{SD})\end{array}$ & $\begin{array}{l}8.04 \text { bc } \\
(0.91)\end{array}$ & $\begin{array}{l}4.99 \mathbf{c} \\
(0.53)\end{array}$ & $\begin{array}{l}161.8 \\
(12.87)\end{array}$ & $\begin{array}{r}50.9 \mathbf{a} \\
(2.88)\end{array}$ & $\begin{array}{c}0.90 \\
(0.18)\end{array}$ & $\begin{array}{l}18.2 \mathbf{b} \\
(2.61)\end{array}$ \\
\hline Papikio & $\begin{array}{l}\text { Mean } \\
(\mathrm{SD})\end{array}$ & $\begin{array}{l}8.40 \mathbf{c} \\
(0.99)\end{array}$ & $\begin{array}{l}5.14 \mathbf{c} \\
(0.69)\end{array}$ & $\begin{array}{l}164.9 \\
(11.95)\end{array}$ & $\begin{array}{l}52.0 \mathbf{a b} \\
(2.56)\end{array}$ & $\begin{array}{c}0.85 \\
(0.11)\end{array}$ & $\begin{array}{l}19.8 \mathbf{c} \\
(1.80)\end{array}$ \\
\hline Dadia & $\begin{array}{l}\text { Mean } \\
(\mathrm{SD})\end{array}$ & $\begin{array}{l}7.81 \text { bc } \\
(1.04)\end{array}$ & $\begin{array}{l}4.79 \text { bc } \\
(0.57)\end{array}$ & $\begin{array}{l}163.9 \\
(11.69)\end{array}$ & $\begin{array}{c}53.4 \text { b } \\
(2.60)\end{array}$ & $\begin{array}{c}0.85 \\
(0.17)\end{array}$ & $\begin{array}{c}18.1 \text { b } \\
(1.85)\end{array}$ \\
\hline ANOVA & & $* * *$ & $* * *$ & ns & $* *$ & $\mathrm{~ns}$ & $* * *$ \\
\hline Shade le & & Length & Width & LI & MWI & Petiole & Veins \\
\hline Elatia & $\begin{array}{l}\text { Mean } \\
(\mathrm{SD})\end{array}$ & $\begin{array}{l}7.80 \mathbf{a} \\
(0.83)\end{array}$ & $\begin{array}{l}4.86 \mathbf{a} \\
(0.62)\end{array}$ & $\begin{array}{l}161.6 \\
(12.11)\end{array}$ & $\begin{array}{l}51.2 \mathbf{a} \\
(2.12)\end{array}$ & $\begin{array}{c}0.76 \\
(0.14)\end{array}$ & $\begin{array}{l}17.1 \mathbf{a} \\
(1.38)\end{array}$ \\
\hline Haidu & $\begin{array}{l}\text { Mean } \\
(\mathrm{SD})\end{array}$ & $\begin{array}{l}7.97 \mathbf{a} \\
(0.82)\end{array}$ & $\begin{array}{l}4.94 \mathbf{a} \\
(0.55)\end{array}$ & $\begin{array}{r}162.09 \\
(9.98)\end{array}$ & $\begin{array}{l}52.6 \mathbf{a b} \\
(2.73)\end{array}$ & $\begin{array}{c}0.70 \\
(0.15)\end{array}$ & $\begin{array}{l}17.9 \mathbf{a} \\
(1.22)\end{array}$ \\
\hline Ehinos & $\begin{array}{l}\text { Mean } \\
(\mathrm{SD})\end{array}$ & $\begin{array}{l}9.26 \mathbf{b} \\
(1.01)\end{array}$ & $\begin{array}{l}5.51 \mathbf{b} \\
(0.57)\end{array}$ & $\begin{array}{l}168.9 \\
(11.1)\end{array}$ & $\begin{array}{l}51.7 \mathbf{a b} \\
(2.03)\end{array}$ & $\begin{array}{c}0.76 \\
(0.17)\end{array}$ & $\begin{array}{r}20.1 \mathbf{b} \\
(2.28)\end{array}$ \\
\hline Papikio & $\begin{array}{l}\text { Mean } \\
(\mathrm{SD})\end{array}$ & $\begin{array}{l}9.24 \mathbf{b} \\
(1.00)\end{array}$ & $\begin{array}{l}5.62 \mathbf{b} \\
(0.69)\end{array}$ & $\begin{array}{l}165.5 \\
(12.68)\end{array}$ & $\begin{array}{l}52.4 \mathbf{a b} \\
(2.70)\end{array}$ & $\begin{array}{c}0.75 \\
(0.13)\end{array}$ & $\begin{array}{r}20.4 \mathbf{b} \\
(1.72)\end{array}$ \\
\hline Dadia & $\begin{array}{l}\text { Mean } \\
(\mathrm{SD})\end{array}$ & $\begin{array}{l}9.06 \mathbf{b} \\
(1.55)\end{array}$ & $\begin{array}{l}5.49 \text { b } \\
(0.78)\end{array}$ & $\begin{array}{l}165.8 \\
(12.81)\end{array}$ & $\begin{array}{r}53.2 \text { b } \\
(2.57)\end{array}$ & $\begin{array}{c}0.81 \\
(0.17)\end{array}$ & $\begin{array}{l}19.6 \mathbf{b} \\
(2.16)\end{array}$ \\
\hline ANOVA & & $* * *$ & $* * *$ & ns & $*$ & $\mathrm{~ns}$ & $* * *$ \\
\hline All popu & & Length & Width & LI & MWI & Petiole & Veins \\
\hline Light & $\begin{array}{l}\text { Mean } \\
(\mathrm{SD})\end{array}$ & $\begin{array}{c}7.71 \\
(1.00)\end{array}$ & $\begin{array}{c}4.77 \\
(0.59)\end{array}$ & $\begin{array}{l}162.57 \\
(12.08)\end{array}$ & $\begin{array}{l}52.18 \\
(2.71)\end{array}$ & $\begin{array}{c}0.88 \\
(0.15)\end{array}$ & $\begin{array}{l}17.8 \\
(2.21)\end{array}$ \\
\hline Shade & $\begin{array}{l}\text { Mean } \\
(\mathrm{SD})\end{array}$ & $\begin{array}{c}8.67 \\
(1.24)\end{array}$ & $\begin{array}{c}5.28 \\
(0.71)\end{array}$ & $\begin{array}{l}164.77 \\
(11.91)\end{array}$ & $\begin{array}{l}52.23 \\
(2.51)\end{array}$ & $\begin{array}{c}0.76 \\
(0.16)\end{array}$ & $\begin{array}{l}19.03 \\
(2.20)\end{array}$ \\
\hline ANOVA & & $* * *$ & $* * *$ & $\mathrm{~ns}$ & ns & $* * *$ & $* * *$ \\
\hline Populati & & Length & Width & LI & MWI & Petiole & Veins \\
\hline ANOVA & & ns & ns & ns & ns & ns & ns \\
\hline
\end{tabular}

expression of the phylogenetic background of populations in the diversity of size and shape under shade leaves, among the populations of this study.

A comparison of the average values of Length and LI for the Rodopi populations in this study with the ones presented for representative parts of the Eurasian expansion of the genus Fagus [12], revealed two different patterns: Populations of the eastern part of Rodopi (Ehinos, Papikio and Dadia) had leaves with average length similar to the ones found in Turkey, W. Georgia, Caucasus and Iran, where F. orientalis grows (Fig. 3a), while the populations of western Rodopi (Elatia and Haidu) had an average lamina length similar to beech populations growing in Bulgaria, a region where the presence of both $F$. sylvatica and $F$. orientalis has been suggested [5, 12]. Average values of LI were similar for all Rodopi populations, as well as for Bulgarian and European beech populations (Fig. 3b). The leaf index is a trait reported to be relatively stable within plants and species, as it is related with the amount of diffusing light inside tree canopy (i.e. the greater leaf index, the higher the light diffusion) and thus has an adaptive relevance for photosynthesis optimization $[26,27]$. It is often used to characterize plant species and has been used to describe Fagus species and subspecies 
Plot of Means
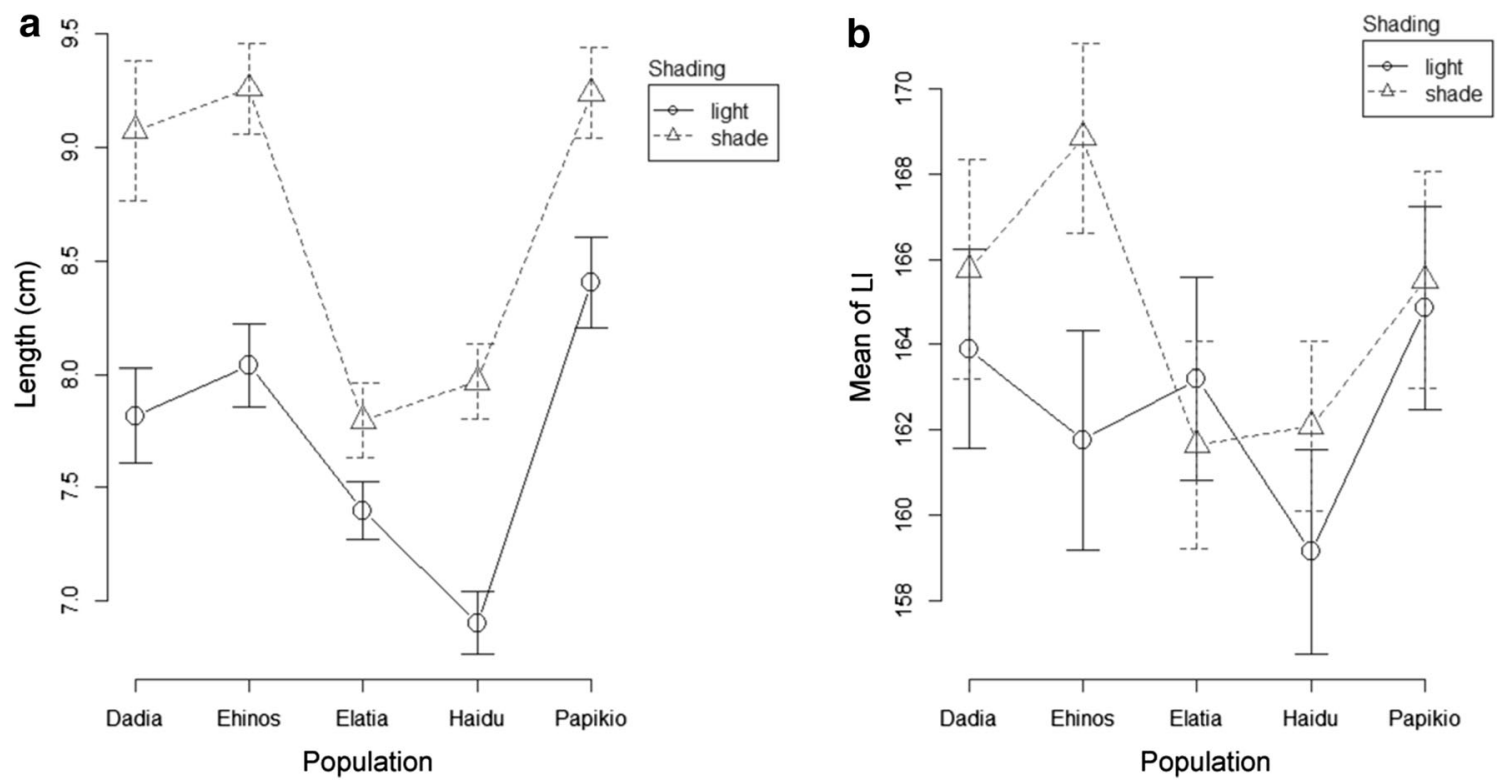

Fig. 2 Means of lamina length (Length) and leaf index (LI) of populations for shade and light leaves

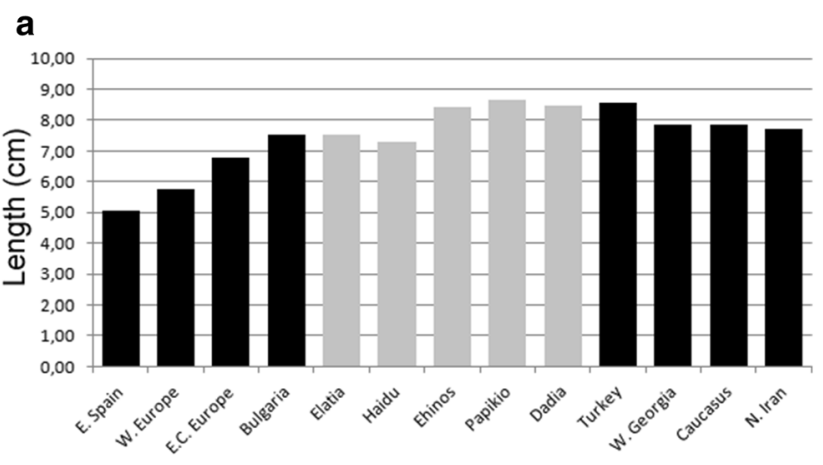

b

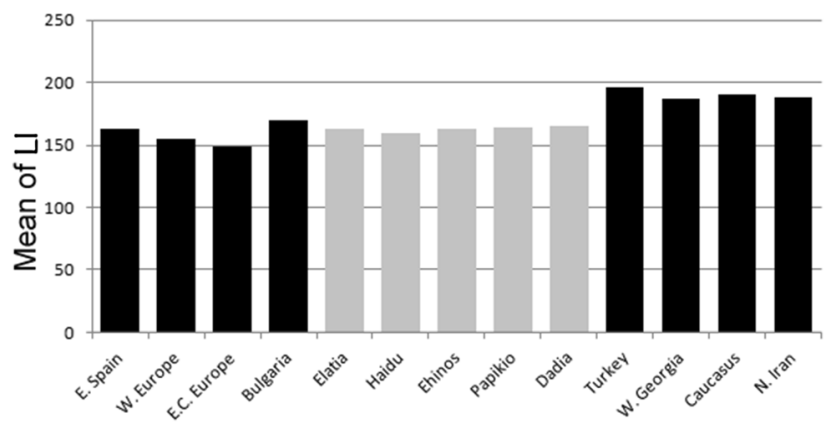

Fig. 3 Comparison of mean lamina length (Length) and leaf index (LI) between the Rodopi populations of this study and other Eurasian beech population groups according to [12]

[12]. According to the leaf index, the beech populations growing on Rodopi mountains seem to belong more to $F$. sylvatica.
The PCA produced similar results for both light and shade leaves. The three first components explained more than $85 \%$ of the total variation (Table 3). The first component expressed mainly leaf size (Length, Width) and the number of veins (Veins), while the second was correlated mainly with leaf shape (LI, MWI). The third component expressed mainly the length of the petiole (Petiole) (Table 4, Fig. 4). The PCA plot of the two first components for light leaves showed an east-west trend in the populations, without a clear grouping pattern (Fig. 5a). On the same plot for shade leaves, differences between eastern and western populations were much stronger and the populations clustered clearly in two groups (Fig. 5b). Our results indicate that diversity patterns of shade leaves seem to correspond with the differences in species composition between beech populations growing in different geographical locations, as described by previous genetic studies on the same populations $[7,8,16]$. Thus, the hypothesis tested in this study that morphological differences among populations may differ between shade and light leaves is confirmed. A first explanation for this observation can be the distinct role of shade leaves in the total plant performance. Since shade leaves mainly utilize diffusing light, their size and shape are independent from light irradiation prevailing at each site. The two distinct geographical groups may reflect different site ecological parameters besides light conditions, i.e. mean annual temperature and air humidity [28]. A second explanation for the population grouping in respect to shade leaves can be a more genetic influence, as already mentioned. Similar 
Table 3 Eigenvalues and representation of the total variance in the first six new dimensions (Dim.) deriving from the PCA for light and shade leaves

\begin{tabular}{lllllll}
\hline Light leaves & Dim.1 & Dim.2 & Dim.3 & Dim.4 & Dim.5 & Dim.6 \\
\hline Eigenvalues & 2.5525 & 1.5747 & 1.0062 & 0.5846 & 0.2801 & 0.0020 \\
Variance \% & 42.54 & 26.24 & 16.77 & 9.74 & 0.03 \\
Cumulative \% & 42.54 & 68.79 & 85.56 & 95.30 & 99.97 & 100.00 \\
Shade leaves & Dim.1 & Dim.2 & Dim.3 & Dim.4 & Dim.5 & Dim.6 \\
Eigenvalues & 2.6728 & 1.3711 & 1.0850 & 0.5965 & 0.2721 & 0.0026 \\
Variance \% & 44.55 & 22.85 & 18.08 & 9.94 & 4.53 & 0.04 \\
Cumulative \% & 44.55 & 67.40 & 85.48 & 95.42 & 99.96 \\
\hline
\end{tabular}

Table 4 a) Correlation coefficients of the variables for the three first PCA dimensions (Dim.), for light and shade leaves. b) Levels of significance; $\mathrm{ns}=$ non significant

\begin{tabular}{|c|c|c|c|c|c|c|}
\hline \multirow{2}{*}{$\begin{array}{l}\text { (a) } \\
\text { Variables }\end{array}$} & \multicolumn{3}{|c|}{ Light leaves } & \multicolumn{3}{|c|}{ Shade leaves } \\
\hline & Dim.1 & Dim. 2 & Dim.3 & Dim.1 & Dim. 2 & Dim.3 \\
\hline Length & 0.971 & -0.054 & -0.020 & 0.967 & -0.046 & -0.093 \\
\hline Width & 0.801 & -0.540 & 0.068 & 0.847 & -0.480 & 0.069 \\
\hline Veins & 0.794 & 0.068 & -0.459 & 0.778 & 0.041 & -0.467 \\
\hline Petiole & 0.430 & 0.090 & 0.863 & 0.508 & -0.005 & 0.757 \\
\hline LI & 0.371 & 0.796 & -0.160 & 0.311 & 0.805 & -0.310 \\
\hline MWI & 0.121 & 0.797 & 0.146 & 0.246 & 0.699 & 0.431 \\
\hline (b) & \multicolumn{3}{|c|}{ Light leaves } & \multicolumn{3}{|c|}{ Shade leaves } \\
\hline Variables & Dim.1 & Dim. 2 & Dim.3 & Dim.1 & Dim.2 & Dim.3 \\
\hline Length & $* * *$ & ns & $\mathrm{ns}$ & $* * *$ & $\mathrm{~ns}$ & ns \\
\hline Width & $* * *$ & $* * *$ & $\mathrm{~ns}$ & $* * *$ & $* * *$ & ns \\
\hline Veins & $* * *$ & ns & $* * *$ & $* * *$ & ns & $* * *$ \\
\hline Petiole & $* * *$ & $\mathrm{~ns}$ & $* * *$ & $* * *$ & $\mathrm{~ns}$ & $* * *$ \\
\hline LI & $* * *$ & $* * *$ & ns & $* * *$ & $* * *$ & $* * *$ \\
\hline MWI & ns & $* * *$ & ns & $* *$ & $* * *$ & $* * *$ \\
\hline
\end{tabular}

differences between light and shade leaves have been observed in several broadleaved species [29]. Furthermore, a possible genetic pattern in the differentiation among plant populations in shade leaves has been reported for the Greek fir [30] and the olive tree [27].

\section{Conclusion}

Various studies related to the description of vegetation, morphological observations, chloroplast DNA haplotypes, nuclear microsatellites and AFLP genomic markers of the beech forests in Rodopi describe differences between the eastern and the western side of the mountain, congruent to our results in leaf morphology. The diversity of lamina size and shape of shade leaves, as shown in this study, seems to follow a similar pattern. Compared with the typical morphological description of the two beech species $F$. sylvatica and $F$. orientalis, the beech forests of the study area appear to have multi-trait phenotypes that are between these two species. However, there is a clear west-east trend in the leaf traits that corresponds to a possible introgression zone of $F$. sylvatica and F. orientalis in Rodopi. This trend is better expressed in shade leaf traits, possibly due to their decreased dependence from light irradiation of each population site.

This west-east trend in leaf morphology may also be the outcome of phenotypic plasticity of beech trees or adaptation of beech populations to different environmental conditions. Common environment trials and studies on functional traits on the beech populations of Rodopi will 


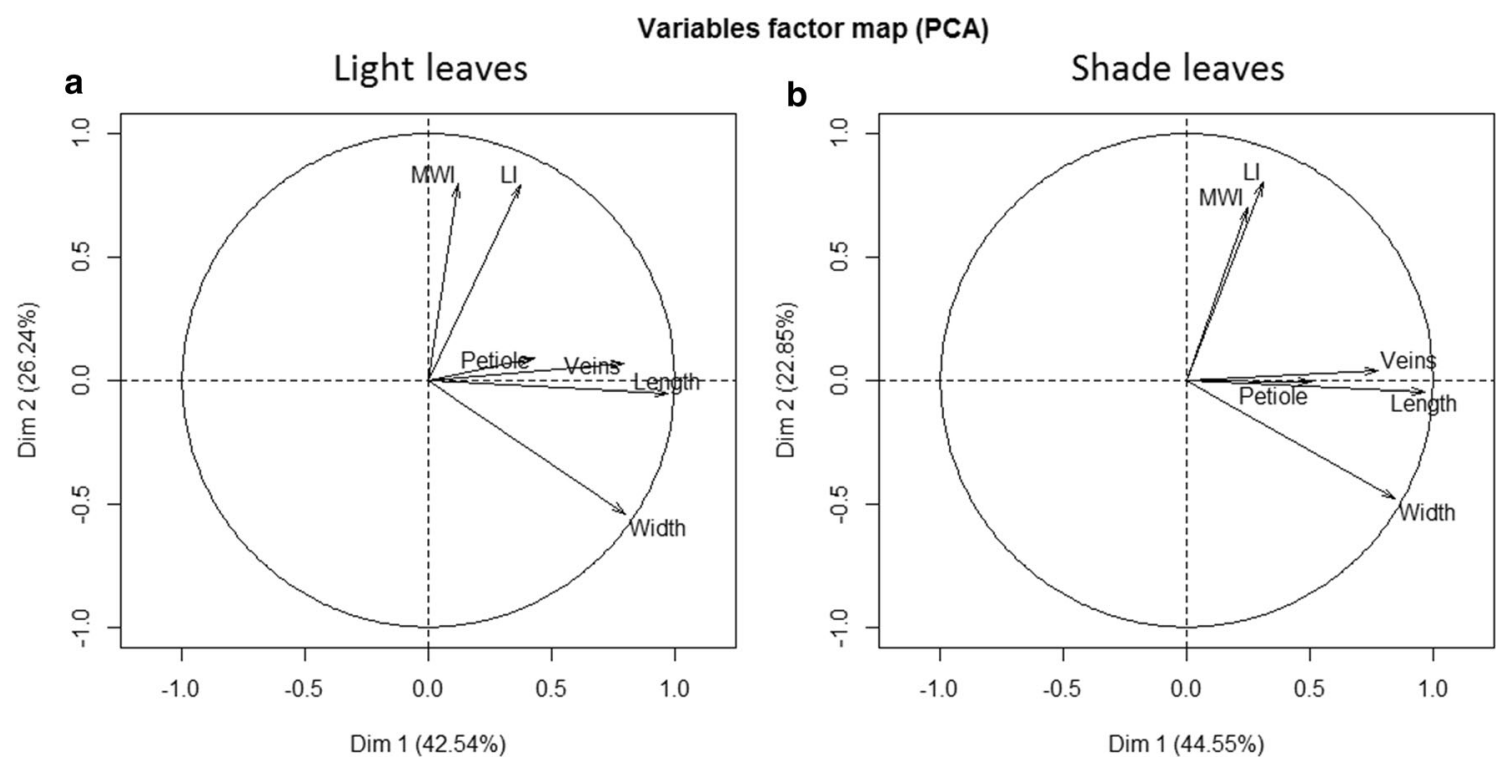

Fig. 4 Plot of variables and the two first PCA axes for light and shade leaves. The arrows correspond to the original variables and their angles to the axes are relevant to their correlation. The size of the arrows reflects their contribution to the total variation

Fig. 5 Population plot of the two first PCA axes for light and shade leaves

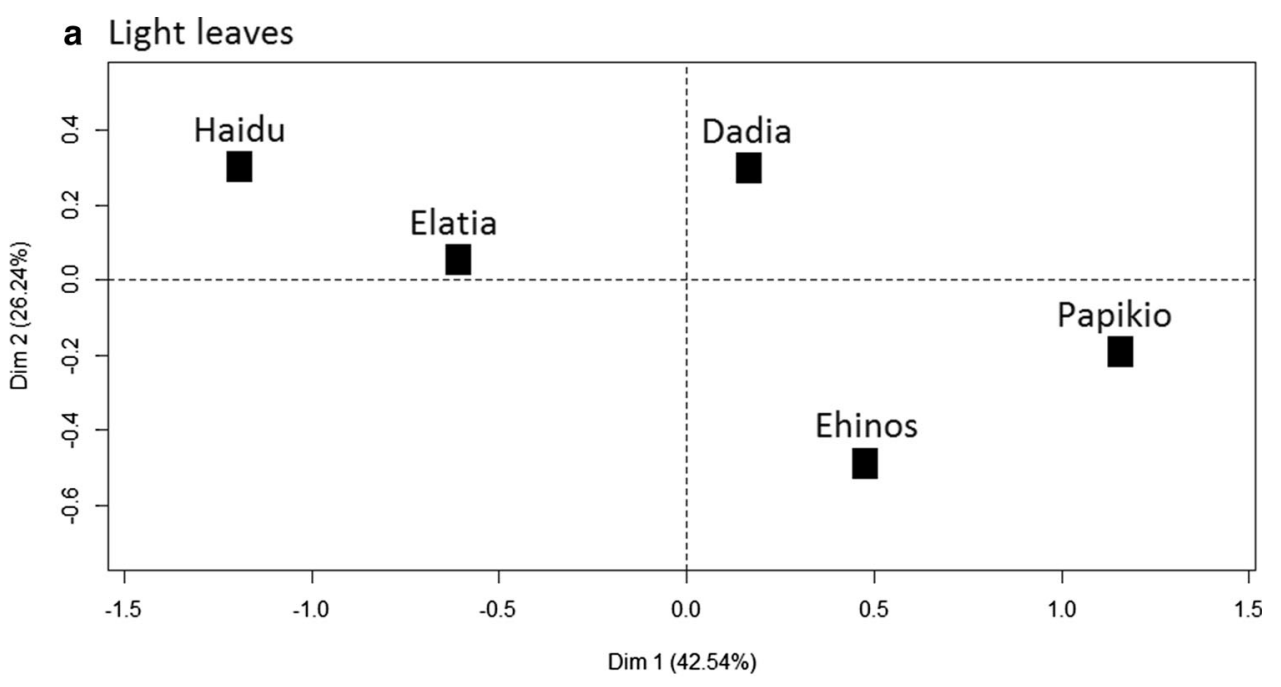

b Shade leaves

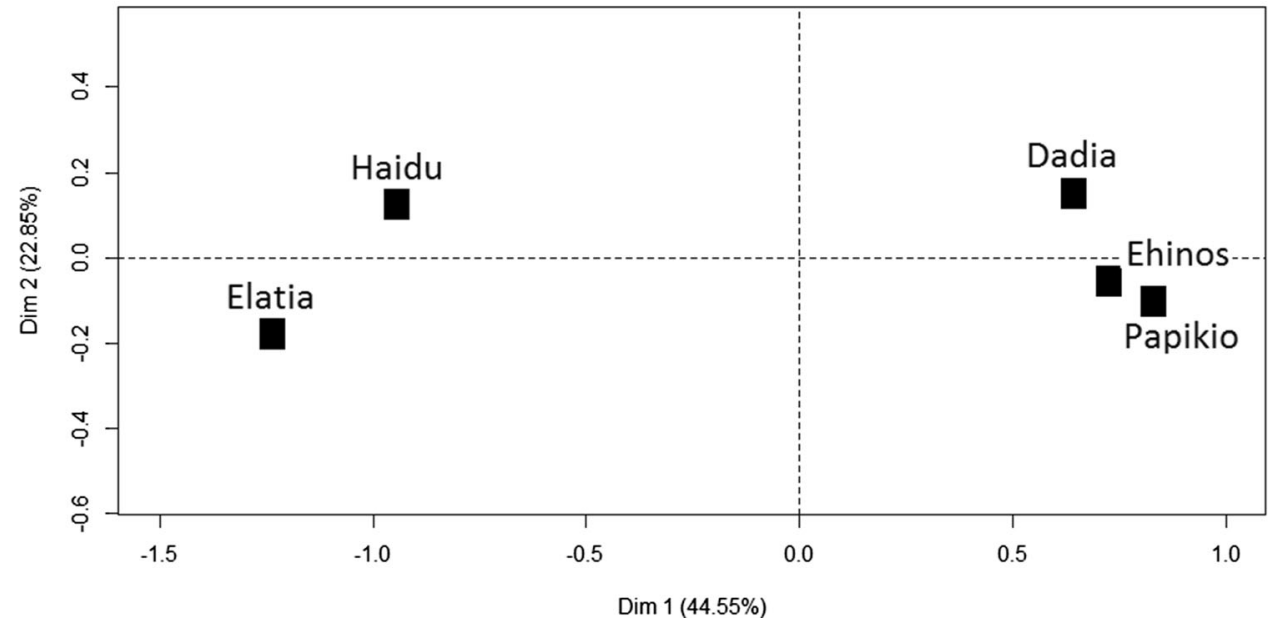


add more valuable information and help design a management strategy for the species towards climate change.

Acknowledgements The authors wish to thank G. Korakis and D. Kasimiadis for their help during sampling.

Funding Open access funding provided by University of Bern.

\section{Compliance with Ethical Standards}

Conflict of interest The authors have declared that there is no conflict of interest.

Open Access This article is licensed under a Creative Commons Attribution 4.0 International License, which permits use, sharing, adaptation, distribution and reproduction in any medium or format, as long as you give appropriate credit to the original author(s) and the source, provide a link to the Creative Commons licence, and indicate if changes were made. The images or other third party material in this article are included in the article's Creative Commons licence, unless indicated otherwise in a credit line to the material. If material is not included in the article's Creative Commons licence and your intended use is not permitted by statutory regulation or exceeds the permitted use, you will need to obtain permission directly from the copyright holder. To view a copy of this licence, visit http://creativecommons. org/licenses/by/4.0/

\section{References}

1. Himanen K, Adem GD, Van Lijsebettens M (2007) Genetic and epigenetic control of leaf size and shape. Int J Plant Develop Biol $1: 226-238$

2. Viscosi V, Antonecchia G, Lepais O, Fortini P, Gerber S, Loy A (2012) Leaf shape and size differentiation in white oaks: assessment of allometric relationships among three sympatric species and their hybrids. Int J Plant Sci 173:875-884

3. Martin RE, Asner GP, Bentley LP et al (2019) Covariance of sun and shade leaf traits along a tropical forest elevation gradient. Front Plant Sci. https://doi.org/10.3389/fpls.2019.01810

4. Govaerts R, Andrews S, Coombes A (2013) World Checklist of Fagaceae. Facilitated by the Royal Botanic Gardens, Kew. http://apps.kew.org/wcsp/. Accessed 4 April 2013

5. Gömöry D, Paule L, Brus R, Zhelev P, Tomovic Z, Gracan J (1999) Genetic differentiation and phylogeny of beech on the Balkan peninsula. J Evol Biol 12:746-754

6. Denk T, Grimm G, Stögerer K, Langer M, Hemleben V (2002) The evolutionary history of Fagus in western Eurasia: evidence from genes, morphology and the fossil record. Plant System Evol 232:213-236. https://doi.org/10.1007/s006060200044

7. Papageorgiou AC, Vidalis A, Gailing O et al (2008) Genetic variation of beech (Fagus sylvatica L.) in Rodopi (N.E. Greece). Euro J Forest Res 127:81-88. https://doi.org/10.1007/s10342-007-0185-3

8. Hatziskakis S, Papageorgiou AC, Gailing O, Finkeldey R (2009) High chloroplast haplotype diversity in Greek populations of beech (Fagus sylvatica L.). Plant Biol 11:425-433. https://doi.org/10.1111/j.1438-8677.2008.00111.x

9. Hatziskakis S, Tsiripidis I, Papageorgiou AC (2011) Leaf morphological variation in beech (Fagus sylvatica L.) populations in Greece and its relation to their post-glacial origin. Botanical J Linnean Soc 165:422-436. https://doi.org/10.1111/j.1095-8339. 2011.01124.x

10. Šijačić Nikolić M, Milovanović J, Nonić M, Knežević R, Stanković D (2013) Leaf morphometric characteristics variability of different beech provenances in juvenile development stage. Genetika 45:369-380. https://doi.org/10.2298/GENSR1302369S

11. Ciocîrlan E (2014) Comparative morphological analyses in marginal beech populations. Bull Transilv Univ Braşov Agric Food Eng 7:7-12

12. Denk T (2003) Phylogeny of Fagus L. (Fagaceae) based on morphological data. Plant Syst Evol 240:55-81. https://doi.org/ 10.1007/s00606-003-0018-x

13. Fox J (2005) The R commander: a basic statistics graphical user interface to R. J Stat Softw 14:1-42

14. Lê S, Josse J, Husson F (2008) FactoMineR: an R package for multivariate analysis. J Stat Softw 25:1-18

15. Bergmeier E, Dimopoulos P (2001) Fagus sylvatica forest vegetation in Greece: syntaxonomy and gradient analysis. J Veg Sci 12:109-126. https://doi.org/10.1111/j.1654-1103.2001.tb02622.x

16. Müller M, Lopez PA, Papageorgiou AC, Tsiripidis I, Gailing O (2019) Indications of genetic admixture in the transition zone between Fagus sylvatica L. and Fagus sylvatica ssp. orientalis Greut. \& Burd. Diversity 11:90. https://doi.org/10.3390/d110 60090

17. Tsiripidis I, Athanasiadis N (2003) Contribution to the knowledge of the vascular flora of NE Greece: floristic composition of the beech (Fagus sylvatica L.) forests in the Greek Rodopi. Willdenowia 33:273-297. https://doi.org/10.3372/wi.33.33207

18. Hovenden MJ, Vander Schoor JK (2004) Nature vs nurture in the leaf morphology of Southern beech, Nothofagus cunninghamii (Nothofagaceae). New Phytol 161:585-594. https://doi.org/ 10.1046/j.1469-8137.2003.00931.x

19. Milla R, Reich P (2011) Multi-trait interactions, not phylogeny, fine-tune leaf size reduction with increasing altitude. Ann Botany 107:455-465. https://doi.org/10.1093/aob/mcq261

20. Lichtenthaler HK, Babani F, Langsdorf G (2007) Chlorophyll fluorescence imaging of photosynthetic activity in sun and shade leaves of trees. Photosynth Res 93:234-244. https://doi.org/10.1007/ s11120-007-9174-0

21. Masarovičová E, Štefančik L (1990) Some ecophysiological features in sun and shade leaves of tall beech trees. Biol Plant 32:374-387. https://doi.org/10.1007/BF02898503

22. Hladká D, Čaňová I (2005) Morphological and physiological parameters of beech leaves (Fagus sylvatica L.) in research demonstration object Pol'ana. J Forest Sci 51:168-176

23. Aranda I, Castro L, Pardos M, Gil L, Pardos JA (2005) Effects of the interaction between drought and shade on water relations, gas exchange and morphological traits in cork oak Quercus suber L. seedlings. Forest Ecol Manag 210:117-129. https://doi.org/10.1016/ j.foreco.2005.02.012

24. Wyka TP, Oleksyn J, Zytkowiak R, Karolewski P, Jagodzinski AM, Reich PB (2012) Responses of leaf structure and photosynthetic properties to intra-canopy light gradients: a common garden test with four broadleaf deciduous angiosperm and seven evergreen conifer tree species. Oecologia 170:1-14. https://doi.org/ 10.1007/s00442-012-2279-y

25. Desotgiu R, Cascio C, Pollastrini M, Gerosa G, Marzuoli R, Bussotti F (2012) Short and long term photosynthetic adjustments in sun and shade leaves of Fagus sylvatica L., investigated by fluorescence transient (FT) analysis. Plant Biosyst 146:206-212. https://doi.org/10.1080/11263504.2012.705350

26. Tsukaya $H$ (2002) The leaf index: heteroblasty, natural variation, and the genetic control of polar process of leaf expansion. Plant Cell Physiol 43:372-378. https://doi.org/10.1093/pcp/pcf051

27. Rubio de Casas R, Vargas P, Perez-Corona E et al (2011) Sun and shade leaves of Olea europaea respond differently to plant size, light availability and genetic variation. Funct Ecol 25:802-812. https://doi.org/10.1111/j.1365-2435.2011.01851.x

28. Shahba MA, Bauerle WL (2009) Growth temperature modulates the spatial variability of leaf morphology and chemical elements 
within crowns of climatically divergent Acer rubrum genotypes. Tree Physiol 29:869-877. https://doi.org/10.1093/treephys/ tpp024

29. Bruschi P, Grossoni P, Bussotti F (2003) Within- and among tree variation in leaf morphology of Quercus petraea (Matt.) Liebl. natural populations. Trees 17:164-172. https://doi.org/10.1007/ s00468-002-0218-y

30. Papageorgiou AC, Kostoudi C, Sorotos I, Varsamis G, Korakis G, Drouzas AD (2015) Diversity in needle morphology and genetic markers in a marginal Abies cephalonica (Pinaceae) population. Ann Forest Res 58:217-234. https://doi.org/10.15287/afr.2015. 410

Publisher's Note Springer Nature remains neutral with regard to jurisdictional claims in published maps and institutional affiliations. 